\title{
José Manuel Guerra-García \\ Caprellids (Crustacea: Amphipoda) from Papua New Guinea, with the description of a new species
}

Received: 12 April 2002 / Accepted: 18 March 2003 / Published online: 23 April 2003

(C) Springer-Verlag and AWI 2003

\begin{abstract}
This is the first study of caprellid amphipods from the coast of Papua New Guinea. Several collections from Madang Lagoon (north) and Bootless Bay (south) have been studied. Seven species in seven genera are recorded, of which Pseudoproto papua sp. nov. is described as new to science. The genus Pseudoproto Mayer, 1903 has consisted, so far, of only one species, Pseudoproto fallax Mayer, 1903. Although only a single male has been found of Pseudoproto papua sp. nov., differences in antennae, mouthparts, gnathopod 2 and pereopods 3 and 4 have revealed that it represents a new species of Pseudoproto. Lateral view figures of all species, together with a key to species level for the Caprellidea from Papua New Guinea are also included.
\end{abstract}

Keywords Crustacea $\cdot$ Caprellidea $\cdot$ Systematics $\cdot$ New species · Papua New Guinea

\section{Introduction}

The caprellid fauna of Papua New Guinea has not been studied so far. Mayer's monographs on the world Caprellidea (Mayer 1882, 1890, 1903) did not report any caprellids from Papua New Guinea, and no references of Papua New Guinea caprellids are included in the Crustacearon Catalogus (McCain and Steinberg 1970). The recent works on the Amphipoda from Papua New Guinea have focused exclusively on the Gammaridea (Lowry and Stoddart 1995; Myers 1995).

During a stay at the Australian Museum, Sydney, the author studied several collections of caprellids from Papua New Guinea. The caprellid material originated

Communicated by H.-D. Franke

J. M. Guerra-García (

Laboratorio de Biología Marina,

Departamento de Fisiología y Biología Animal,

Facultad de Biología, Universidad de Sevilla,

Avda Reina Mercedes 6, 41012 Seville, Spain

e-mail: jmguerra@us.es

Fax: +34-954-233480 from two different sampling programmes, along Madang Lagoon (north) and Bootless Bay (south), respectively (Fig. 1).

The collections on the north coast of Papua New Guinea, Madang Province, were made by J.D. Thomas, J.K. Lowry, A. Myers, M. Jebb and S. Keable during January/February 1990, and March/April 1991, as a part of an international project to study the amphipods of the Madang Lagoon and adjacent areas. Although the project was targeted on the Gammaridea (Lowry and Stoddart 1995; Myers 1995), some caprellid samples were collected, sorted and maintained in the collections of the Australian Museum. An account of the natural history (geological history and the physical and biological

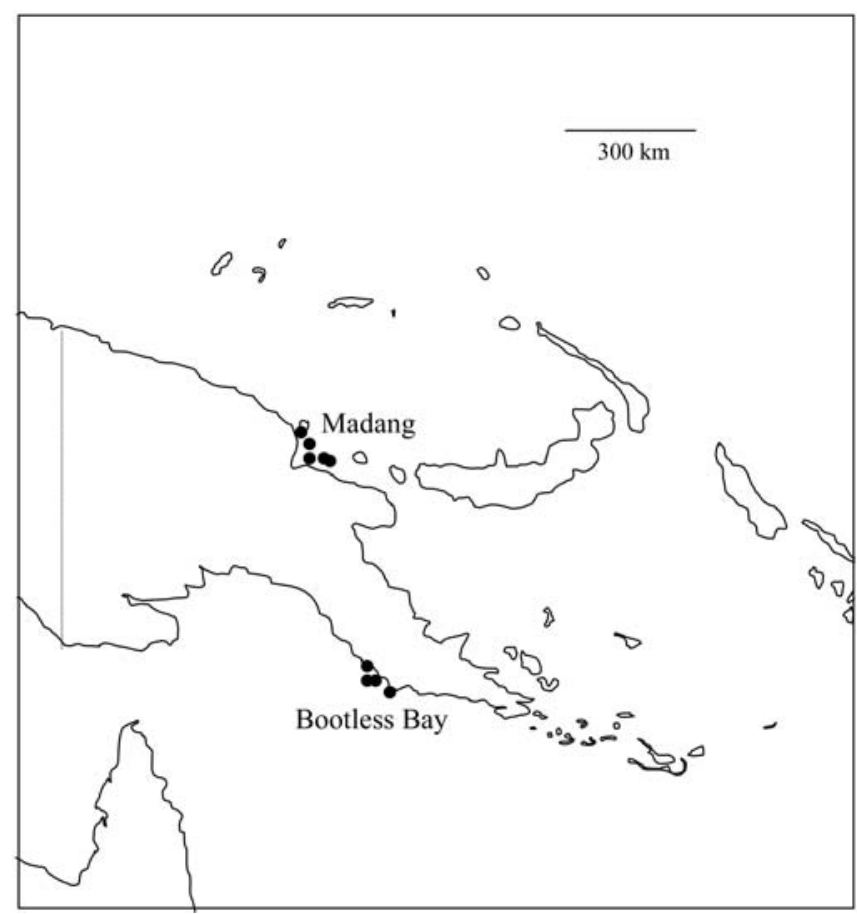

Fig. 1 Map of Papua New Guinea showing the sampling localities 


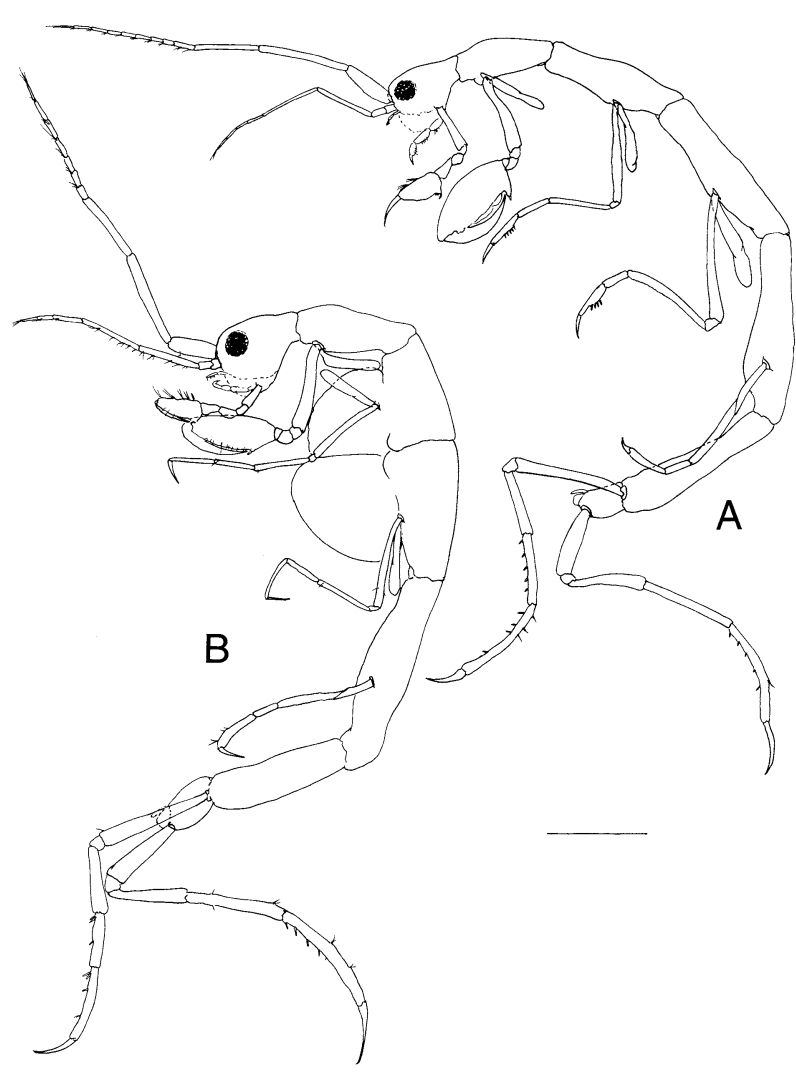

Fig. 2A, B Metaproto novaehollandiae (Haswell, 1880). Lateral view. A Male. B Female. Scale bar: $1 \mathrm{~mm}$

oceanography), together with a map of the study area and a detailed list of all stations, is given in Jebb and Lowry (1995). The collections from Bootless Bay (south) and nearby areas were made by J.K. Lowry and S. Arnam in October/November 1980. Seven caprellid species were identified; one of them, P. papua sp. nov., is described as a new species in this paper.

The examined specimens for the present study are deposited in the following institutions: AM Australian Museum, Sydney, Australia; USNM National Museum of Natural History, Smithsonian Institution, Washington D.C., USA; ZMA Zoologisch Museum, Amsterdam, The Netherlands; ZMUC Zoological Museum, University of Copenhagen, Copenhagen, Denmark.

\section{Systematics}

Family Phtisicidae Vassilenko, 1968

Metaproto novaehollandiae (Haswell, 1880)

See Fig. 2.

Proto novae-hollandiae Haswell, 1880:275-276, pl. 2,

Fig. 3; Mayer, 1882:26; Stebbing, 1888:1230-1232; Mayer 1890:14-15.

Metaproto novaehollandiae Mayer, 1903:26-27, pl. 1,

Figs. 11, 12, pl. 6, Figs. 24-28, pl. 9, Figs. 3, 50;
Stebbing, 1910:651-652; McCain and Steinberg, 1970:56; Laubitz 1991:103-104, Fig. 1.

\section{Material examined (AM P61550 to P61553)}

PNG-11: 3 males, 1 female; PNG-19: 3 females; PNG-59: 1 male, 1 female; JKL/PNG-147: 1 female.

\section{Remarks}

The genus Metaproto can be easily distinguished from the remaining genera of the family Phtisicidae by the presence of only one pair of abdominal appendages. The specimens examined in the present study are in agreement with those described by Haswell (1880) and redescribed by Mayer (1903) and Laubitz (1991), and with specimens collected from the Philippines and Queensland, Australia, examined by the author. This species is under redescription based on specimens collected from New South Wales, close to the type locality (Takeuchi, in preparation). The specimens collected from Papua New Guinea were in poor condition and most of the pereopods were lacking, so the lateral view figures of the species included in the present paper are redrawn from Guerra-García (2002a).

\section{Ecology}

The ecology of Metaproto novaehollandiae is still poorly known: this species has been found between 4 and $790 \mathrm{~m}$ depth, living among antipatharians and echinoderms (Laubitz 1991). In the present study, the species was found on soft bottoms, living in coarse sand and sandy bottoms next to small reef patches.

\section{Distribution}

Type locality: Port Jackson, Australia (Haswell 1880). Other records: Banda Sea, Indonesia, South Africa (McCain and Steinberg 1970), New Caledonia and the Philippines (Laubitz 1991). New record for Papua New Guinea.

\section{Protogeton inflatus Mayer, 1903}

See Fig. 3.

Protogeton inflatus Mayer, 1903:28-29, pl. 1, Fig. 13, pl. 6, Figs. 29-32, pl. 9, Figs. 11, 35, 51; Utinomi, 1947:69. 


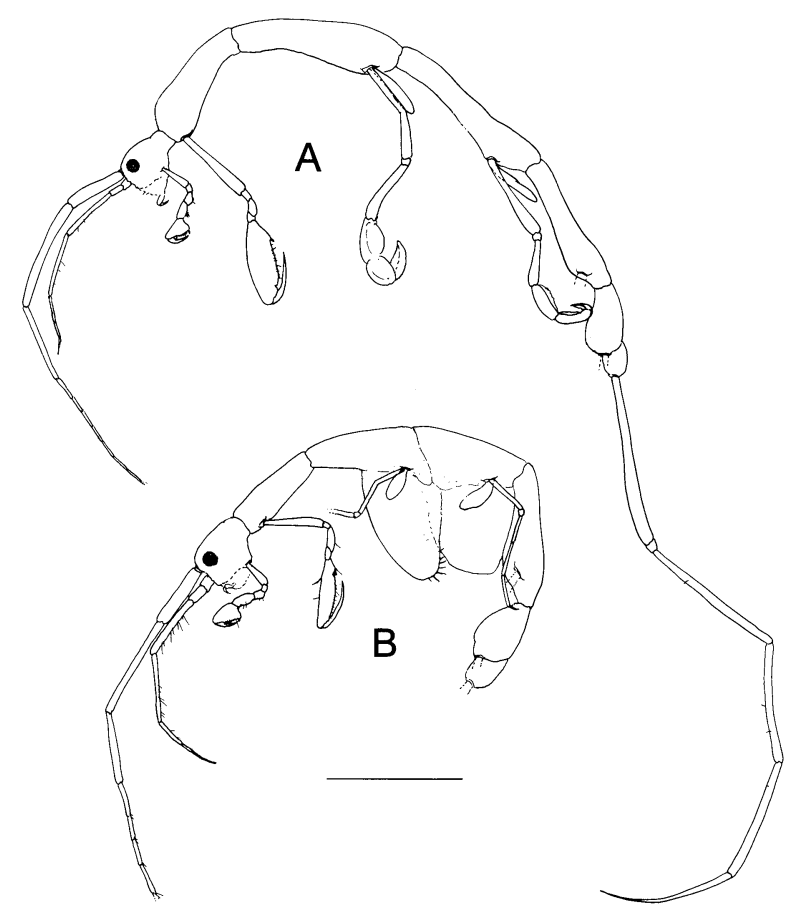

Fig. 3A, B Protogeton inflatus Mayer, 1903. Lateral view. A Male. B Female. Scale bar: $1 \mathrm{~mm}$

\section{Material examined}

PNG-55: 2 males, 1 female (AM P61554); type material (syntypes): 1 male (Fig. 3A), 1 female (Fig. 3B) ZMA Amph. 107194.

\section{Remarks}

The genus Protogeton is characterised by the absence of abdominal appendages. This character is also present in the genus Pseudoproto Mayer, 1903, which also belongs to the Phtisicidae. Nevertheless, the feature of pereopods 3 and 4 in male Protogeton inflatus is unique for the Caprellidea; the carpus, propodus and dactylus are curved, and show lateral expansions. Furthermore, the mandibular palp is reduced to one article in Protogeton while it is normally three-articulate in Pseudoproto. The specimens studied from Papua New Guinea are in agreement with the type material described by Mayer (1903) from Indonesia. Taking into consideration that the $P$. inflatus material collected in Papua New Guinea was not in a good condition to draw the lateral view, we have illustrated here the type material of the species to make the use of the Papua New Guinea caprellids key easier.

\section{Ecology}

In the present study, the species has been found living in sand and silt bottoms.

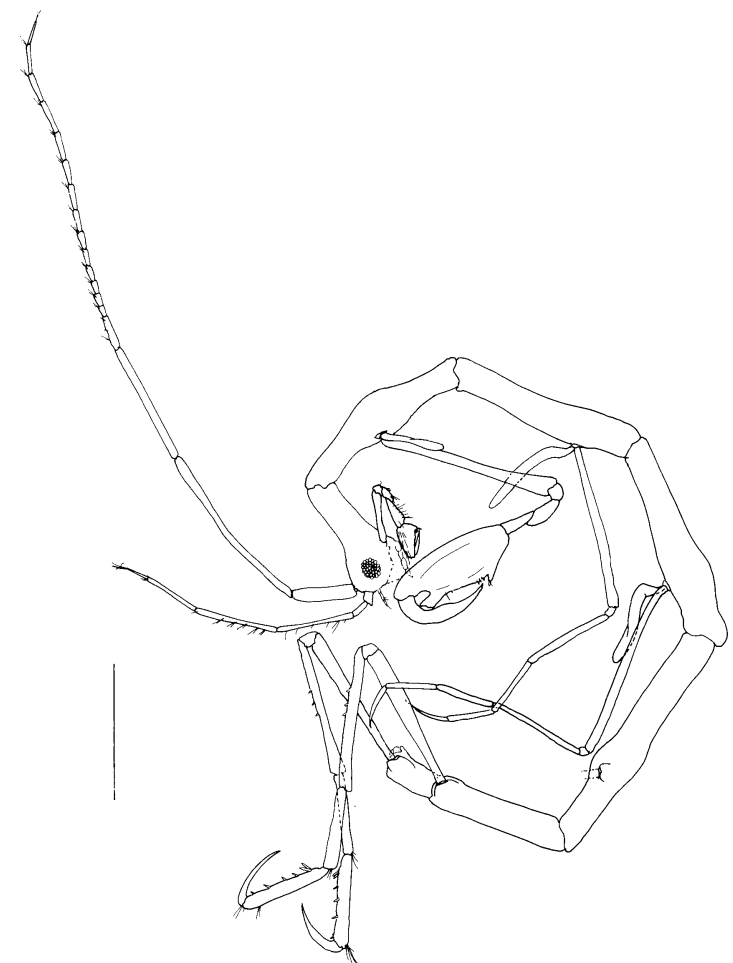

Fig. 4 Pseudoproto papua sp. nov. Male lateral view. Scale bar: $1 \mathrm{~mm}$

\section{Distribution}

Type locality: Dongala, Celebes, Indonesia (McCain and Steinberg 1970). Other records: Tanabe Bay, Japan (McCain and Steinberg 1970); the Philippines (GuerraGarcía, 2002a). New record for Papua New Guinea.

\section{Pseudoproto papua n.sp.}

See Figs. 4, 5, 6, 7, 8 .

\section{Type material}

Holotype male PNG-55 (AM P61555) collected from Manunouha Island, northeast end, sand and silt bottom, 20-23 m, J.K. Lowry, 5 November 1980.

\section{Etymology}

Named after Papua, the name given to the people of Papua New Guinea by early Portuguese sailors.

\section{Description}

Holotype male

Body length: $7.7 \mathrm{~mm}$. 


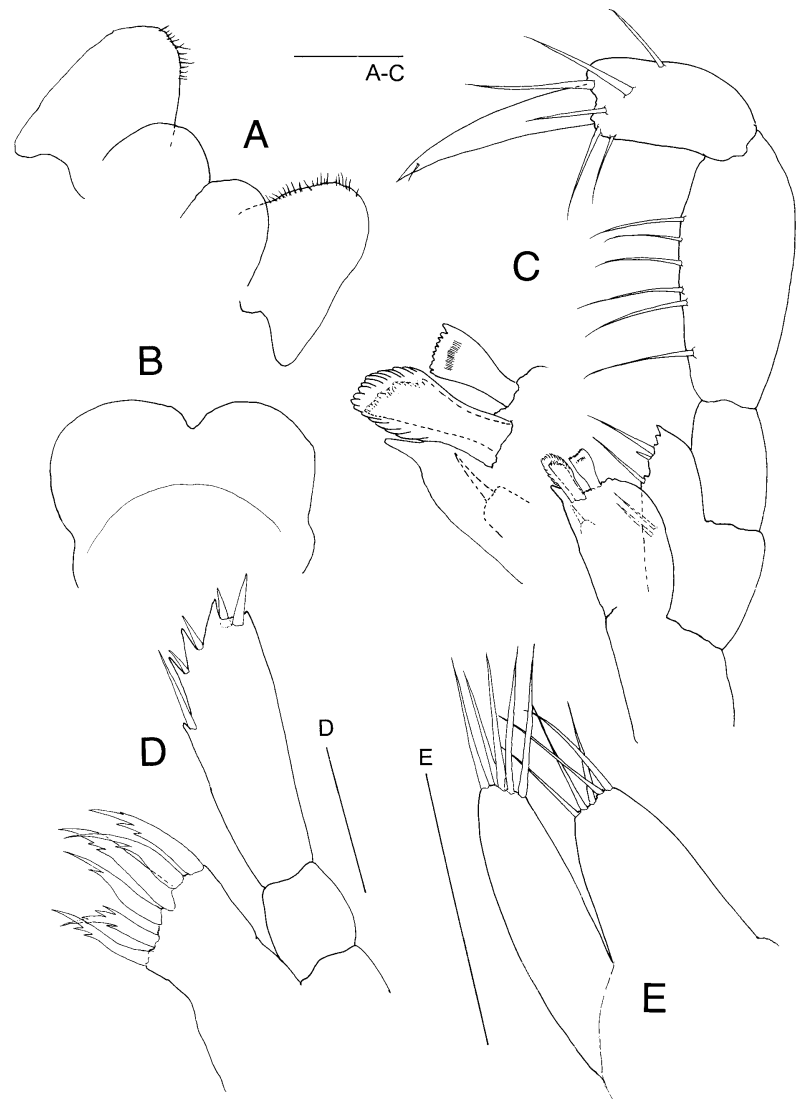

Fig. 5A-E $P$. papua sp. nov. A Lower lip. B Upper lip. C Maxilliped. D Maxilla 1. E Maxilla 2. Scale bars: $0.05 \mathrm{~mm}$

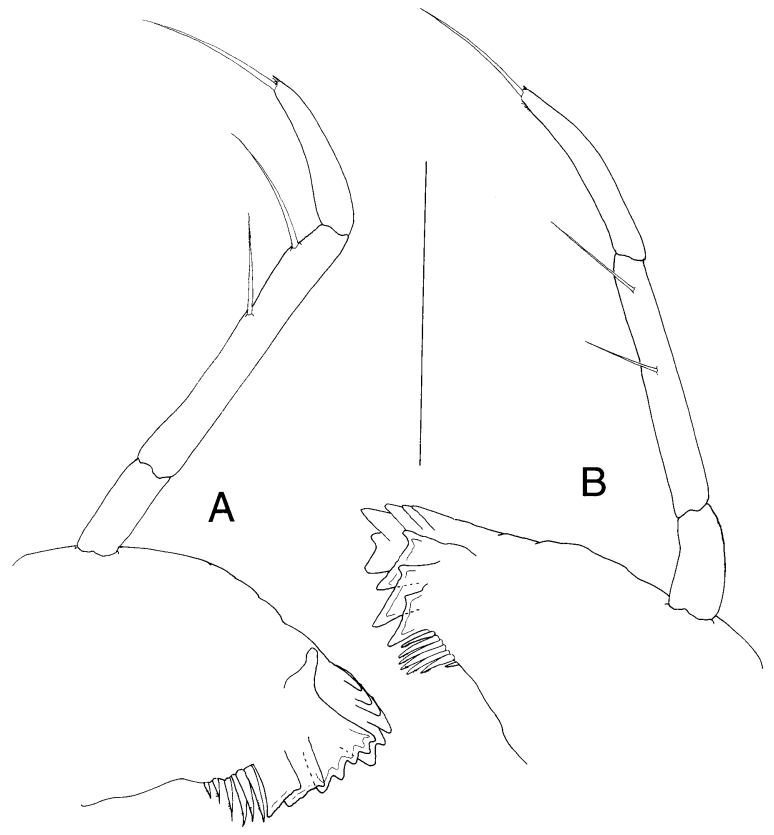

Fig. 6A, B $P$. papua sp. nov. a Left mandible. b Right mandible. Scale bar: $0.1 \mathrm{~mm}$

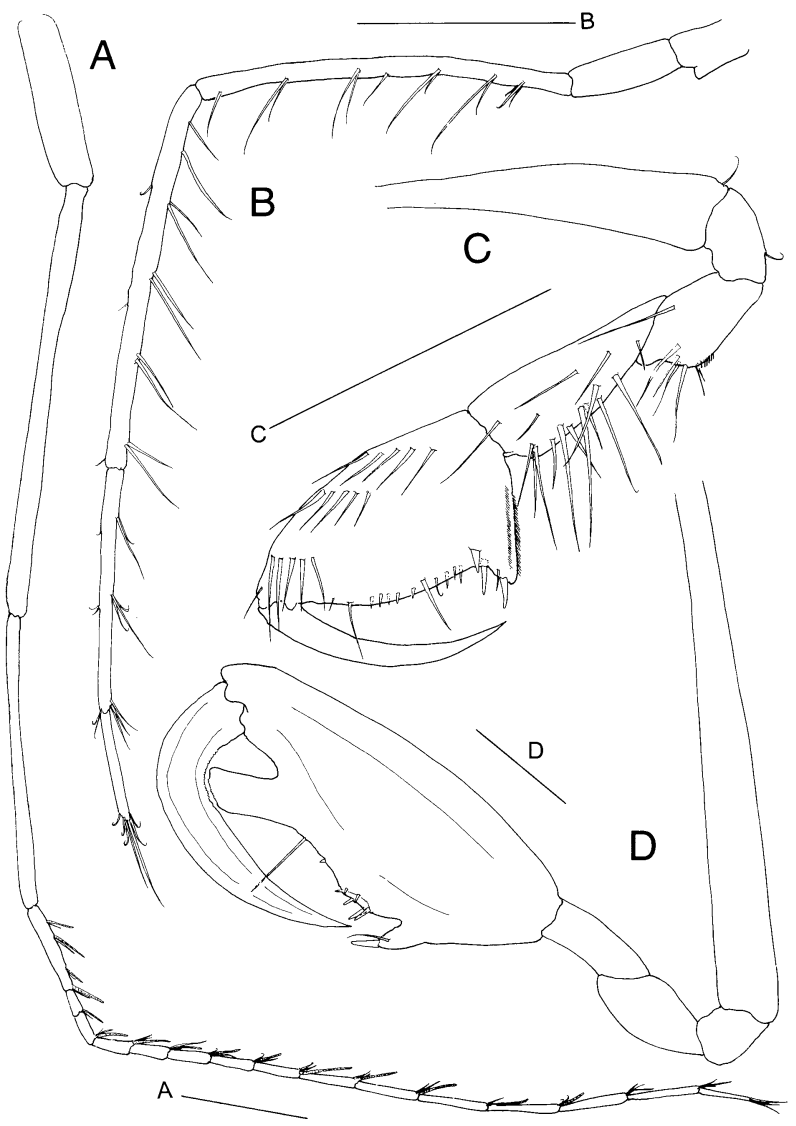

Fig. 7A-D $P$. papua sp. nov. A Antenna 1. B Antenna 2. C Gnathopod 1. D Gnathopod 2. Scale bars: A, B $0.5 \mathrm{~mm}$; C $0.3 \mathrm{~mm}$; D $0.2 \mathrm{~mm}$

Lateral view (Fig. 4). Body dorsally smooth, elongate. Head rounded. Pereonite 1 fused with head, suture not present; pereonites $2-5$ increasing slightly in length; pereonite 7 the shortest.

Gills (Fig. 4). Present on pereonites 2-4. Elongate, length about six times width.

Mouthparts. Upper lip (Fig. 5B) symmetrically bilobed, smooth apically. Mandibles (Fig. 6A, B) with three-articulate palp; distal article of palp with a single seta; second article provided with two simple setae; mandibular molar absent; left mandible with incisor sixtoothed, lacinia mobilis five-toothed followed by two plates and six plumose setae; incisor of right mandible six-toothed, lacinia mobilis transformed in a plate minutely serrate, followed by two more plates, six plumose setae and a tiny simple one; molar flake absent. Lower lip (Fig. 5A) with inner lobes well demarcated; outer lobes provided with setulae on apical end. Maxilla 1 (Fig. 5D): outer lobe with six robust serrate setae; distal article of the palp with five robust setae and four teeth distally, no setae medially. Maxilla 2 (Fig. 5E): inner lobe oval, carrying five setae distally; outer lobe elongate and slightly larger than inner lobe, with five apical setae. Maxilliped (Fig. 5C): inner plate carrying three robust nodular setae (like teeth) distally, and one simple seta 


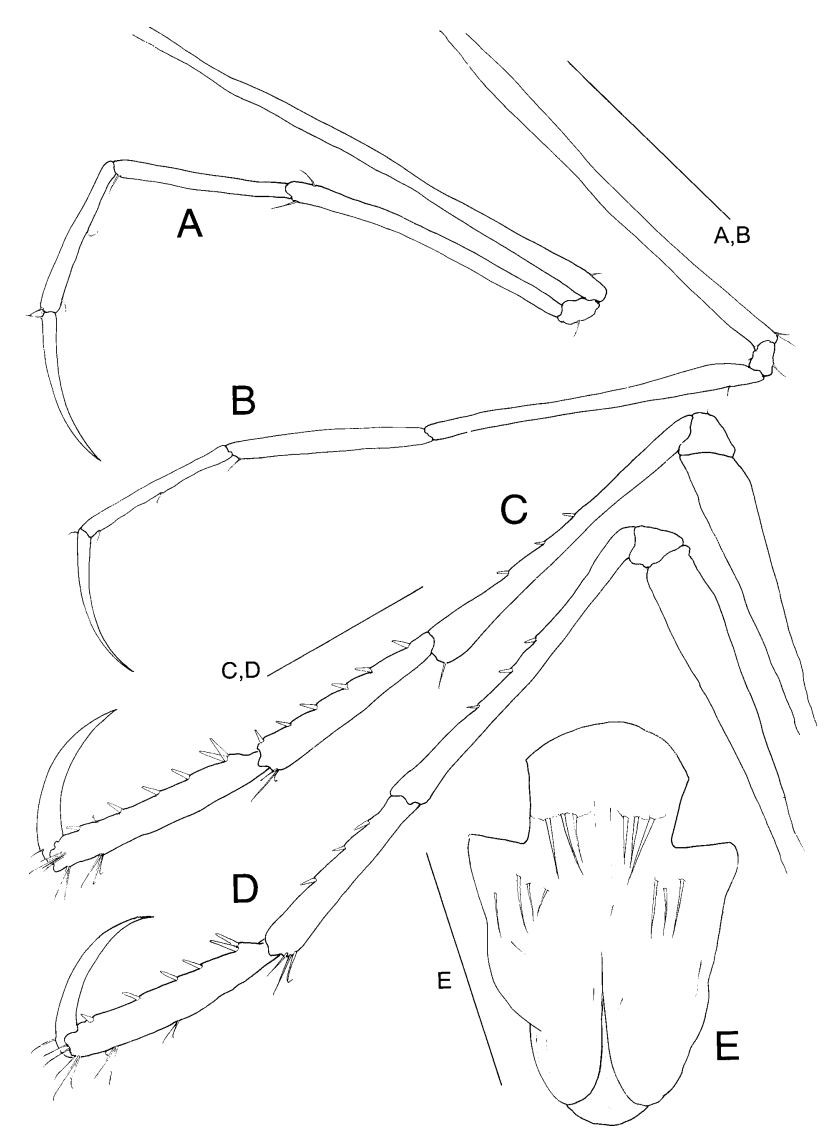

Fig. 8A-E P. papua sp. nov. A Pereopod 3. B Pereopod 4. C Pereopod 6. D Pereopod 7. E Abdomen (ventral view). Scale bars: A-D $0.5 \mathrm{~mm}$; E $0.1 \mathrm{~mm}$

medially; outer plate smaller than inner plate with five setae and denticulate margin; palp four-articulate, dactylus without rows of setulae.

Antennae. Antenna 1 (Fig. 7A) about 3/4 of body length; flagellum 15-articulate; peduncular articles 2 and 3 elongate. Antenna 2 (Fig. 7B) provided with short setae (not swimming setae); proximal article of the peduncle with a small projection distally; flagellum elongate, twoarticulate.

Gnathopods. Gnathopod 1 (Fig. 7C) basis as long as ischium, merus and carpus combined; carpus elongate and setose; propodus triangular, palm with three proximal grasping spines and a row of short setae; dactylus smooth. Gnathopod 2 (Fig. 7D) inserted in the middle of pereonite 2 ; basis as long as pereonite 2; ischium rectangular; merus rounded but elongate; carpus rectangular; propodus elongate, about $3 / 4$ as long as the basis; palm with a proximal round projection provided with one grasping spine followed by three pairs of short spines and a striking rectangular projection distally; dactylus long, minutely denticulate on the proximal half, without setulae on ventral margin.

Pereopods. Pereopods 3 (Fig. 8A) and 4 (Fig. 8B) subequal, six-articulate. Ischium short and rectangular. Propodus without grasping spines. Pereopod 5 missing.
Pereopods 6 (Fig. 8C) and 7 (Fig. 8D) subequal. Merus, carpus and propodus with robust spines ventrally.

Penes (Fig. 8E) triangular, situated laterally.

Abdomen (Fig. 8E) without appendages, with a pair of lateral lobes and a single dorsal lobe.

\section{Remarks}

Although pereopod 5 was missing in the specimen examined, it has been assigned to the genus Pseudoproto on the basis of the absence of abdominal appendages. The genus Protogeton is the only other genus in the Phtisicidae without abdominal appendages, but presents only two pairs of gills (on pereonites 3 and 4) while the genus Pseudoproto has three pairs of gills (on pereonites 2-4). The genus Pseudoproto Mayer, 1903 was, so far, composed of only one species, P. fallax Mayer, 1903. The type material of $P$. fallax (ZMUC-CRU-6398) has been examined for comparison. As no adult males were available (4 females, 1 juvenile), additional material of $P$. fallax collected on the Australian coast (Guerra-García, in preparation) has been consulted as well, together with the original description of Mayer (1903). P. papua sp. nov. can be distinguished from $P$. fallax mainly on the basis of the following characteristics: (1) the striking distal projection on the propodus palm of male gnathopod 2 present in $P$. papua is lacking in $P$. fallax; (2) the propodus of pereopods 3 and 4 has grasping spines in $P$. fallax but none in $P$. papua; (3) antenna 1 is clearly longer than half body length in $P$. papua and shorter in $P$. fallax; (4) $P$. papua presents only one distal single seta on the third article of the mandibular palp while $P$. fallax presents 3 or 4 following the formula $1-\mathrm{x}-1$, with $\mathrm{x}=1-2$.

\section{Ecology}

The single specimen was found living on sand and silt bottoms 20-23 m deep.

\section{Distribution}

Known only from the type locality: Manunouha Island, $9^{\circ} 32.0^{\prime} \mathrm{S} 147^{\circ} 16.5^{\prime} \mathrm{E}$, northeast end, Papua New Guinea.

\section{Quadrisegmentum triangulum Hirayama, 1988}

SeeFig. 9.

Quadrisegmentum triangulum Hirayama, 1988:10891093, Figs. 1-3.

\section{Material examined (AM P61533 to P61537)}

PNG-23: 3 males, one female; PNG-32: 1 female; PNG63: 3 males, 1 female; PNG AJB 206: 1 male; PNG AJB 


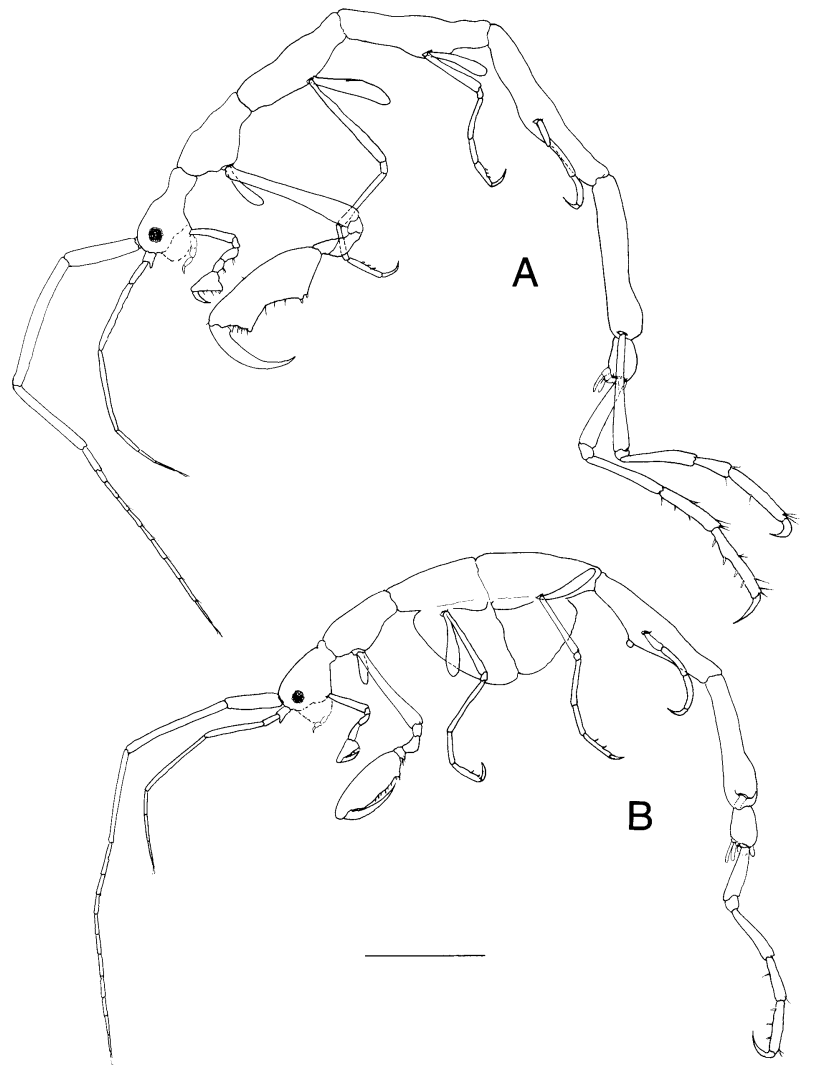

Fig. 9A, B Quadrisegmentum triangulum Hirayama, 1988. Lateral view. A Male. B Female. Scale bar: $1 \mathrm{~mm}$

208: 3 males; JKL/PNG-68: 1 male; JKL/PNG-69: many specimens.

\section{Remarks}

The genus Quadrisegmentum was recently established by Hirayama (1988), being a monospecific genus with $Q$. triangulum as the type species. The genus is unique in the subfamily Phtisicinae in having four-articulate fifth pereopods. The material examined from Papua New Guinea is in agreement with the specimens described by Hirayama (1988).

\section{Ecology}

The specimens studied by Hirayama (1988) were collected from a gorgonian host, Isis hippurus. In the present study, the species has been found living in sandy bottoms, on Halimeda opuntia, different species of gorgonians and sponges.

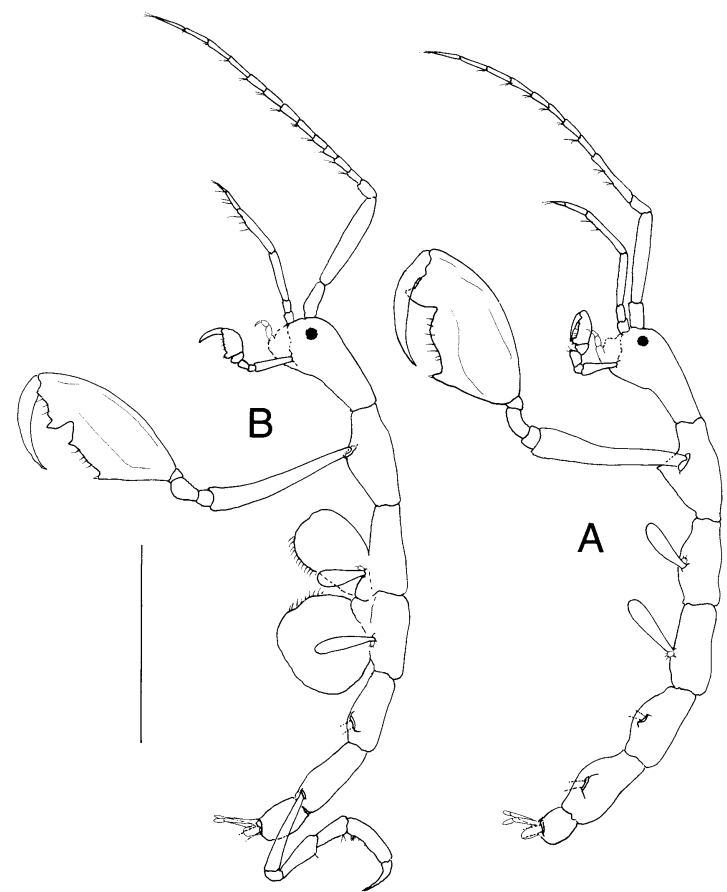

Fig. 10A, B Hemiagina minuta Mayer, 1890. Lateral view. A Male. B Female. Scale bar: $1 \mathrm{~mm}$

\section{Distribution}

Type locality: west islet of Ashmore Reef, northwest Australia $\left(12^{\circ} 14.28^{\prime} \mathrm{S} 122^{\circ} 59.14^{\prime} \mathrm{E}\right)$ (Hirayama 1988). Other records: Queensland, Australia and Solomon Islands (Guerra-García, in preparation). New record for Papua New Guinea.

Family Caprellidae Leach, 1814

\section{Hemiaegina minuta Mayer, 1890}

See Fig. 10.

Hemiaegina minuta Mayer, 1890:40, pl. 1, Figs. 2527, pl. 3, Figs. $32-35$, pl. 5, Figs. 52-53, pl. 6, Figs. 13, 33-34, pl. 7, Fig. 4; McCain, 1968:61-64, Figs. 29-30; McCain and Steinberg, 1970:51; Gable and Lazo-Wasem, 1987:637; Müller, 1990:836; Serejo, 1997:631, Fig. 1.

Hemiaegina quadripunctata Sundara Raj, 1927:126127, pl. 18.

Hemiaegina costai Quitete, 1972 :165-168, pls. 1-2.

Material examined (AM P61547 to P61549)

PNG-13: 1 female; PNG-41: 1 female; PNG-52: 1 male. 


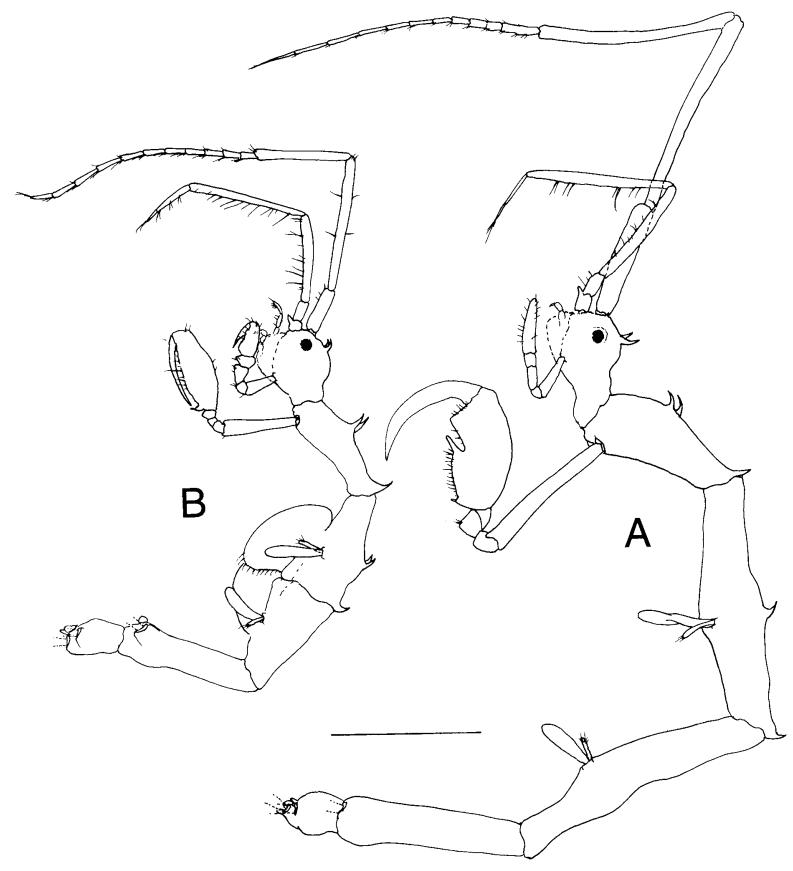

Fig. 11A, B Metaprotella sandalensis Mayer, 1898. Lateral view. A Male. B Female. Scale bar: $1 \mathrm{~mm}$

\section{Remarks}

H. minuta is widely distributed in tropical and temperate waters of the world oceans (Müller 1990).

\section{Ecology}

H. minuta has been collected from Sargassum sp. and taken in plankton tows (McCain and Steinberg 1970). Müller (1990) reported $H$. minuta preferring more or less exposed reef locations. In the present study, the species has been found living in Dyctiota sp., Halimeda macrolopia, Gracilaria sp., Galaxaura sp. and Amansia glomerata.

\section{Distribution}

Type locality: off Amoy, China, 15-46 m deep (McCain 1968). Other records: off Bermuda; Virginia; Cape Hatteras, North Carolina; Elliot Key, Florida; Loggerhead Key, Tortugas; $29^{\circ} 44^{\prime} \mathrm{N} 88^{\circ} 23.5^{\prime} \mathrm{W}$; Port Aransas, Texas; St. John, Virgin Islands; False Bay, South Africa; Oahu, Hawaii; Bora Bora; Sunohama and Tateyama, Japan; $1^{\circ} 42.5^{\prime} \mathrm{S} 130^{\circ} 47.5^{\prime} \mathrm{E}$; Fremantle, Australia; Krusadai Island, India; South Arabian coast (McCain and Steinberg 1970). New record for Papua New Guinea.

\section{Metaprotella sandalensis Mayer, 1898}

See Fig. 11.
Metaprotella sandalensis Mayer, 1898:53-56, Figs. 16; Mayer, 1903 (included f. ralumiana, singaporensis, dolichocephala, gisserana, amboinensis, typica): 40-42, pl. 1, Figs. 30-31, 34-36, pl. 6, Figs. 56-63, pl. 9, figs.16-17, 44, 60; Müller, 1990:836-842, Figs. 41-64.

\section{Material examined (AM P61538 to P61545)}

PNG-14: 3 males; PNG-19: 1 male, 1 juvenile; PNG-38: 1 premature female; PNG-41: 5 males, 3 females; PNG-63: 1 male; PNG AJB 208: 1 female; JDT/PNG-20: 1 male; JKL/PNG-165: 1 juvenile.

\section{Remarks}

M. sandalensis has been recently redescribed in detail by Müller (1990). This species is very common in shallow waters of the tropical Indopacific Ocean (Müller 1990). The present specimens have been assigned to the species $M$. sandalensis on the basis of dorsal projections' arrangement and the absence of a marked suture between head and pereonite 1 (Larsen 1997). Recently, GuerraGarcía (2002b) has described a new species of Metaprotella from Tanzania very similar to $M$. sandalensis. Although the genus Metaprotella has been recently revised by Larsen (1997) and a complete key to Metaprotella species is provided (Larsen 1997; GuerraGarcía 2002b), a molecular approach would probably reveal the existence of cryptic species inside the complex.

\section{Ecology}

Poorly known until now. Müller (1990) reported that $M$. sandalensis prefers unexposed locations as none of his specimens was from the exposed sampling stations on the crest of the barrier reefs at Morea. In the present study, the species was found living on algae (Galaxaura sp.), telestaceans, gorgonians, sponges, soft corals, sand-shell bottoms and coral rubble. This species seems to be very abundant along coral reef habitats.

\section{Distribution}

Type locality: Sandal Bay, Lifu, Loyalty Islands (McCain and Steinberg 1970). Other records: Labuan Badjo, Borneo; Dongala, Celebes; Pulu Tongkil and $6^{\circ} 07.5^{\prime} \mathrm{N}$ $120^{\circ} 26^{\prime} \mathrm{E}$, Sulu Sea; Amboina; between Gisser and Ceram-Laut, Ceram Sea; Singapore, Malaysia; Koh Chang and Koh Kahdal, Thailand; Dutch Bay, Ceylon; Sharks Bay and Cockburn Sound, Australia; Viti Levu, Fiji Islands; Aranuka and Tapeteucea, Gilbert Islands; Ralum, $4^{\circ} 20^{\prime} \mathrm{S} 152^{\circ} 10 \mathrm{~W}$; Oahu and Lisiansky Islands, Hawaiian Islands (McCain and Steinberg 1970); Bora Bora and Morea, Society Islands (Müller 1990). New record for Papua New Guinea. 


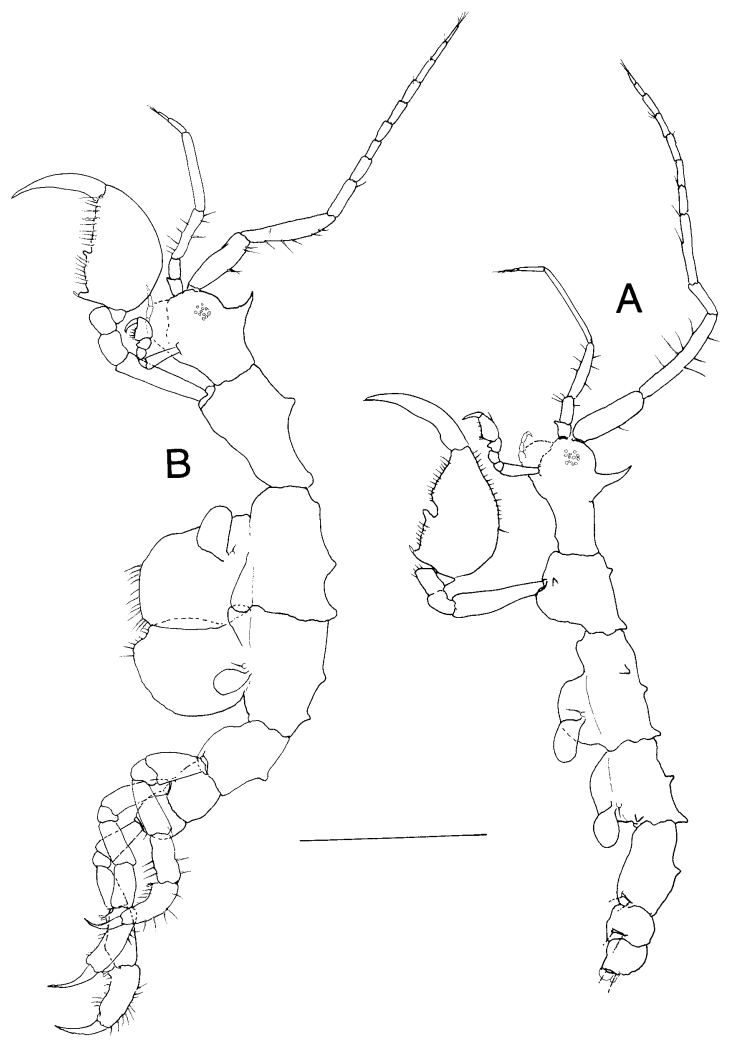

Fig. 12A, B Pseudaeginella biscaynensis McCain, 1968. Lateral view. A Male. B Female. Scale bar: $1 \mathrm{~mm}$

Pseudaeginella biscaynensis (McCain, 1968)

See Fig. 12.

Fallotritella biscaynensis McCain, 1968:58-61, Figs. 27-28, 53; McCain and Steinberg, 1970:51; Gable and Lazo-Wasem, 1987:637-638.

Pseudaeginella biscaynensis Laubitz, 1995: 88.

\section{Material examined}

PNG-14: 4 males, 1 female (AM P61546); type material: male holotype (USNM 120179), female allotype (USNM 120180), 6 males paratypes (USNM 120183-86, 88), 3 females paratypes (USNM 120182-87).

\section{Remarks}

Laubitz (1995) considered the genus Fallotritella synonymous with Pseudaeginella. The material of Pseudaeginella examined from Papua New Guinea is in agreement with the type material of the P. biscaynensis, although there are minor differences on body projections and pereopod 5, which could be attributed to intraspecific variation. The specimens of Pseudaeginella studied here are very similar to the specimens recently studied from Tanzania (Guerra-García 2002c), although they differ in the arrangements of body projections. P. biscaneynsis, described from the western North Atlantic (McCain 1968), has recently been found in the Indian Ocean (Guerra-García 2002c) and the Pacific (this study). Hence, the species is probably cosmopolitan, and the lack of records around the world is probably due to its small size and its usual covering by detritus. Nevertheless, we cannot discard the possibility that there is a complex of very similar but different species. This problem is rather common for other species of the Caprellidea (e.g. Caprella penantis, C. scaura, Metaprotella sandalensis). Future molecular analysis could be helpful in these cases.

\section{Ecology}

The species has been found living on red algae (McCain 1968), the green alga Avrainvillea and the sea-grass Thalassia (Gable and Lazo-Wasem 1987), among corals, through Cymodocea and Syringodium (Guerra-García 2002c), on the seaweed Galaxaura sp. (present study).

\section{Distribution}

Type locality: Bear Cut, Key Biscayne, Florida, 2 m deep (McCain 1968). Other records: Bermuda; Soldier Key, Key Largo and Long Key, Florida; Tortugas; Barbuda; Pigem Island, Santa Lucia (McCain 1968; Gable and Lazo-Wasem 1987); Tanzania (Guerra-García 2002c). New record for Papua New Guinea.

\section{Key to the species of Papua New Guinea}

This species key is meant as an easy field guide to be used without dissection. McCain (1968) includes a lateral view of a generalised caprellid showing the names of the different body parts. Consultation of this figure could be helpful in using the following key:

1. Gills on pereonites 2, 3 and 4 (2)

- Gills on pereonites 3 and 4 only (4)

2. Pereopod 5 four-articulate. Male gnathopod 2 propodus with a triangular projection distally. Abdomen with two pairs of appendages Quadrisegmentum triangulum (Fig. 9)

- Pereopod 5 five-articulate (3)

3. Male gnathopod propodus without distal projection. Antenna 1 shorter than half of the body. Abdomen with one pair of appendages Metaproto novaehollandiae (Fig. 2)

- Male gnathopod propodus with a rectangular distal projection. Antenna 1 longer than half of the body. Abdomen without appendages Pseudoproteo papua sp. nov. (Figs. 4, 5, 6, 7, 8)

4. Pereopods 3 and 4 six-articulate, pereopods 5-7 very elongate Protogeton inflatus (Fig. 3) 
- Pereopods 3 and 4 reduced to one article, pereopods 5-7 not elongate (5)

5. Body smooth Hemiagina minuta (Fig. 10)

- Body with dorsal projections (6)

6. Pereonites 6 and 7 fused. Head with two dorsal projections. Pereopods 3 and 4 elongate, about half of gill length Metaprotella sandalensis (Fig. 11)

- Pereonites 6 and 7 not fused. Head with one dorsal projection. Pereopods 3 and 4 very tiny, much smaller than half of gill length Pseudaeginella biscaynensis (Fig. 12)

Acknowledgements The author is very grateful to Dr. P.B. Berents for her kindness and hospitality during the stay at the Australian Museum. Thanks are also due to J.D. Thomas, J.K. Lowry, A. Myers, M. Jebb and S. Keable for collecting the samples. Many thanks to E. Nelson (USNM), D. Platvoet (ZMA) and J. Olesen (ZMUC) for making available the type material of Pseudaeginella biscaynensis, Pseudoproto fallax and Protogeton inflatus, respectively. The work was supported by a grant AP 9828617065 from the Ministry of Education, Culture and Sport from Spain and a Visiting Collection Fellowship from the Australian Museum.

\section{Appendix}

List of stations

PNG-11: East of Manunouha Island, $9^{\circ} 32.0^{\prime} \mathrm{S} 147^{\circ} 16.5^{\prime} \mathrm{E}$, coarse sand and shell patch at base of coral reef, $10 \mathrm{~m}$, J.K. Lowry and S. Arnam, 26 October 1980.

PNG-13: East of Manunouha Island, $9^{\circ} 32.0^{\prime} \mathrm{S}$ $147^{\circ} 16.5^{\prime} \mathrm{E}$, in Dictyotales and Halimeda macrolopia and Gracilaria, coarse sand and shell patch at base of coral reef, 10 m, J.K. Lowry and S. Arnam, 26 October 1980.

PNG-14: East of Manunouha Island, $9^{\circ} 32.0^{\prime} \mathrm{S}$ $147^{\circ} 16.5^{\prime} \mathrm{E}$, in algae Galaxaura, coarse sand and shell patch at base of coral reef, J.K. Lowry and S. Arnam, 26 October 1980.

PNG-19: Horseshoe Reef, Bootless Inlet, $9^{\circ} 30.5^{\prime} \mathrm{S}$ $147^{\circ} 15.5^{\prime} \mathrm{E}$, outer barrier, steep sand-shell slope at base of front face, $30 \mathrm{~m}, \mathrm{~S}$. Arnam, 28 October 1980.

PNG-23: Horseshoe Reef, Bootless Inlet, $9^{\circ} 30.5^{\prime} \mathrm{S}$ $147^{\circ} 15.5^{\prime} \mathrm{E}$, base of reef slope, outer face, Halimeda opuntia, $30 \mathrm{~m}$, S. Arnam and J.K. Lowry, 28 October 1980.

PNG-32: Horseshoe Reef, Bootless Inlet, $9^{\circ} 30.5^{\prime} \mathrm{S}$ $147^{\circ} 15.5^{\prime} \mathrm{E}$, coral rubble from reef front slope, $12-15 \mathrm{~m}$, J.K. Lowry, 29 October 1980.

PNG-38: Motupore Island, $9^{\circ} 31.5^{\prime} \mathrm{S} 147^{\circ} 17.0^{\prime} \mathrm{E}$, coral rubble from west side, S. Arnam and J.K. Lowry, 30 October 1980.

PNG-41: Motupore Island, $9^{\circ} 31.5^{\prime} \mathrm{S} \quad 147^{\circ} 17.0^{\prime} \mathrm{E}$, Galaxaura from west side, S. Arnam and J.K. Lowry, 30 October 1980.

PNG-52: west of Loloata Island, $9^{\circ} 32.0^{\prime} \mathrm{S} 147^{\circ} 17^{\prime} \mathrm{E}$, grass beds, mainly Amansia glomerata, $1.5 \mathrm{~m}, \mathrm{~J} . \mathrm{K}$. Lowry and S. Arnam, 4 November 1980.
PNG-55: Manunouha Island, $9^{\circ} 32.0^{\prime} \mathrm{S} \quad 147^{\circ} 16.5^{\prime} \mathrm{E}$, northeast end, sand and silt bottom, 20-23 m, J.K. Lowry, 5 November 1980.

PNG-59: between Lion Island and Taurama Point, $9^{\circ} 30^{\prime} \mathrm{S} 147^{\circ} 07^{\prime} \mathrm{E}$, sandy bottom, $12 \mathrm{~m}, \mathrm{~J} . \mathrm{K}$. Lowry and S. Arnam, 8 November 1980.

PNG-63: outside Horseshoe Reef, Bootless Inlet, $9^{\circ} 30.5^{\prime} \mathrm{S} 147^{\circ} 17.5^{\prime} \mathrm{E}$, telestacean from sandy bottom, 44 m, J.K. Lowry and S. Arnam, 9 November 1980.

PNG AJB 206: Bootless Bay, southern Papua New Guinea, $9^{\circ} 30^{\prime} \mathrm{S} 147^{\circ} 07^{\prime} \mathrm{E}$, gorgonian sp3, J.K. Lowry and S. Arnam, 1980.

PNG AJB 208: Bootless Bay, southern Papua New Guinea, $9^{\circ} 30^{\prime} \mathrm{S} 147^{\circ} 07^{\prime} \mathrm{E}$, gorgonian sp1, J.K. Lowry and S. Arnam, 1980.

JDT/PNG-20: Guzem Natum reef $5^{\circ} 09.29^{\prime} \mathrm{S}$ $145^{\circ} 48.37^{\prime} \mathrm{E}$, formalin wash of rubble, coral rubble, plates of Acropora cytherea upside down and algalcovered, J.D. Thomas, 24 February 1990.

JKL/PNG-68: the Quarry, near the village of Bunu 2, $4^{\circ} 46.5^{\prime} \mathrm{S} 145^{\circ} 48^{\prime} \mathrm{E}$, steep coral slope straight off the beach with large unstable rubble and sand, black sponge, $12 \mathrm{~m}$, J.K. Lowry, 21 January, 1990.

JKL/PNG-69: the Quarry, near the village of Bunu 2, $4^{\circ} 46.5^{\prime} \mathrm{S} 145^{\circ} 48^{\prime} \mathrm{E}$, steep coral slope straight off the beach with large unstable rubble and sand, many Didemnum molle with encrusting sponges on dead Acropora branch, 10 m, J.K. Lowry, 21 January, 1990.

JKL/PNG-147: south-eastern corner of Tab (Pig) Island $5^{\circ} 10.31^{\prime} \mathrm{S} 145^{\circ} 50.32^{\prime} \mathrm{E}$, baited trap 7 next to small patch reef on coarse sandy bottom, $28 \mathrm{~m}$, J.K. Lowry and S.J. Keable, 27-28 February 1991.

JKL/PNG-165: Mizegwadan (Tripod) reef, $5^{\circ} 9.57^{\prime} \mathrm{S}$ $145^{\circ} 49.36^{\prime} \mathrm{E}$, soft corals and encrusting Montipora, baited trap 5, 14 m, J.K. Lowry and S.J. Keable, 2-3 March 1991.

\section{References}

Gable MF, Lazo-Wasem EA (1987) The Caprellids (Amphipoda: Caprellida) of Bermuda: a survey of specimens collected from 1876-1987, including cave inhabitants, and the description of Deutella aspiducha, new species. Proc Biol Soc Wash 100: 629-639

Guerra-García JM (2002a) Littoral caprellids (Crustacea: Amphipoda: Caprellidea) from Philippines, with the description of a new species. Raffles B Zool 50:395-406

Guerra-García JM (2002b) Metaprotella tanzaniensis, a new caprellid (Crustacea: Amphipoda) from Tanzania, with a key to the species of Metaprotella and discussion on the family Protellidae. Bull Mar Sci 70:909-918

Guerra-García JM (2002c) Redescription of five rare caprellids (Crustacea: Amphipoda: Caprellidea) collected from Tanzanian coasts. Helgol Mar Res 55:221-231

Haswell WA (1880) On some Amphipods from Australia and Tasmania. Proc Linn Soc New South Wales 5: 97-105

Hirayama A (1988) A ghost shrimp with four-articulate fifth pereopods (Crustacea: Caprellidea: Phtisicidae) from Northwest Australia Zool Sci 5:1089-1093

Jebb MHP, Lowry JK (1995) Natural history of Madang Lagoon with an appendix of collecting localities. In: Lowry JK (ed) The Amphipoda (Crustacea) of Madang Lagoon, Papua New 
Guinea. Part 1. Records of the Australian Museum, Supplement 22:1-24

Larsen K (1997) A new species of Metaprotella (Crustacea: Amphipoda: Caprellidea) from east Africa, with key to the genera of Protellidae and discussion of generic characters. J Nat Hist 31:1203-1212

Laubitz DR (1991) Crustacea Amphipoda Caprellidea: Caprellids from the western Pacific (New Caledonia, Indonesia and the Philippines). In: Crosnier A (ed) Résultats des Campagnes MUSORSTOM, vol 9. Mém Mus Natl Hist Nat (A) 152:101123

Laubitz DR (1995) Caprellidea (Crustacea: Amphipoda) from the Southern and Western Indian Ocean. Mésogée 54:81-100

Lowry JK, Stoddart HE (1995) The Amphipoda (Crustacea) of Madang Lagoon: Lysianassidae, Opisidae, Uristidae, Wandinidae and Stegocephalidae. In: Lowry JK (ed) The Amphipoda (Crustacea) of Madang Lagoon, Papua New Guinea. Part 1. Records of the Australian Museum, Supplement 22:97-174

Mayer P (1882) Caprelliden. Fauna Flora Golf Neapel 6:1-201
Mayer P (1890) Die Caprelliden des Golfes von Neapel und der angrenzenden Meeres-Abschnitte. Fauna Flora Golf Neapel $17: 1-55$

Mayer P (1903) Die Caprelliden der Siboga-Expedition. Siboga Exped 34:1-160

McCain JC (1968) The Caprellidae (Crustacea: Amphipoda) of the western North Atlantic. Bull US Natl Mus 278:1-147

McCain JC, Steinberg JE (1970) Amphipoda-I, Caprellidea-I, Family Caprellidae. In: Gruner HE, Holthuis LB (eds) Crustaceorum Catalogus 2:1-78

Müller HG (1990) New species and records of coral reef inhabiting Caprellidae from Bora Bora and Moorea, Society Islands (Crustacea: Amphipoda). Rev Suisse Zool 97: 827-842

Myers AA (1995) The Amphipoda (Crustacea) of Madang Lagoon: Aoridae, Isaeidae, Ischyroceridae and Neomegamphopidae. In: Lowry JK (ed) The Amphipoda (Crustacea) of Madang Lagoon, Papua New Guinea. Part 1. Records of the Australian Museum, Supplement 22:25-95 